Conference Report

\title{
Notes on the third Drama in Education Days 2017
}

\author{
Drama and theatre in language teaching and learning, held at \\ the Konstanz University of Applied Sciences, 30th of June - 1st \\ of July 2017
}

\section{Eva Göksel \& Stefanie Giebert}

After two successful conferences (2015 \& 2016) at Reutlingen University, the third Drama in Education Days was held at Konstanz University of Applied Sciences, June $30^{\text {th }}$ and July $1^{\text {st }}$, 2017. The bilingual (English/German) conference focuses on best practice and research in the field of drama and theatre in education in second and foreign language teaching, and is organised by Dr. Stefanie Giebert (Konstanz University of Applied Sciences, Germany) und MA Eva Göksel (Centre for Oral Communication, University of Teacher Education Zug, Switzerland). The two-day event caters to teachers, scholars, and performers working with drama and theatre in language education at all levels - primary through to tertiary. This year's conference attracted 45 participants from 9 countries including Austria, Canada, France, Germany, Kirgizstan, Spain, Switzerland, the US, and the UK.

The conference kicked off Thursday, June $29^{\text {th }}$, with a hands-on preconference workshop, during which Tomáš Andrášik (Masaryk University) demonstrated how improv theatre creates a positive classroom atmosphere and fosters communication skills. In the space of two hours, workshop participants tested out techniques to lower communicative anxiety and to develop public speaking skills. Exercises aimed at building self-confidence in speaking and listening and to empower spontaneous and authentic communication were also presented. The evening wrapped up a conference-warming dinner.

The two days were organised into lectures and workshops, which were run in parallel sessions with one English and one German track. Friday morning featured a keynote speech by teacher/scholar Adrian Haack (Göttingen University): “Teachers as actors/performers/artists... or just themselves?!' What drama in education can do for teacher training - without turning teachers into drama queens (and kings)". Focusing on the need for beginning teachers to first explore their "teaching selves" through drama, Haack shared anecdotes from his own practice and from his work with student teachers using drama in education. Student teacher reflections included thoughts about improved public speaking skills and higher self-confidence thanks to encounters with drama-based pedagogies.

Bettina Christner (Indiana University) raised the issue of neglected areas of teacher training, such teacher roles and spontaneity. The talk addressed 
questions such as: How do I present myself as a teacher in front of a class? How can I find my space and (individual and professional) role within the classroom? How can I share and open up this space for the learners? The talk presented opportunities for using performative techniques such as tableaux, thought-tapping, and running the gauntlet to prepare teachers of varying experience for the challenges and joys of the classroom. A lively discussion followed and was continued during the adjacent coffee break.

Anke Stöver-Blahak (Hannover University) reported on a joint project between the Leibniz University Hannover and the Hannover State Theatre. As part of a language acquisition course, university students studying German as a foreign language created their own performances based on a German-language play currently playing at the state theatre. In addition to performing their own work, the students watched the play at the state theatre, thus experiencing language learning holistically, as an audience and as performers.

Carolin Peschel (University of Cologne) shared her approach to teaching about inclusion in teacher education: "There's only one way to look at things - until someone shows us how to look with different eyes". The talk presented preliminary results of a 2-semester course for Bachelor students, which was conducted at the University of Cologne in the 2017 academic year. In concordance with a broad concept of 'inclusion', the course tested a drama-based negotiation of issues of heterogeneity -in the fields of interculturality, as well as social/emotional development- with the aim of developing a possible 'inclusion competence' including: cognitive/linguistic, perceptive, and interactional dimensions.

Alexandra Zimmermann (Wilfrid Laurier University, Waterloo) discussed the potential of drama and theatre in education to act as a "back door to literature" - a way to motivate learners to encounter literature as actors rather than as students. It was proposed that in the process of studying a script, students automatically deal intensively with both (foreign) language and (literary) content. The argument was put forward that the use of abridged texts reduces scripts to manageable portions, which students accept to work with. Based on a current university theatrical project ("The Longing for the Blue Flower"), the talk demonstrated how poetic foreign language texts could be presented effectively using different staging techniques and choreographies.

Nina Kulovics (Haute-Alsace University, Mulhouse) and Aline Vennemann (Lycée Jean-Henri Lambert) presented a German-French fairy tale project "Hinter dem Himmel schlafen die Märchen" ("Fairy Tales Sleep Behind the Sky"). The project proposes that fairy tales be more strongly integrated into both German and French as a foreign language lessons and that additionally, German and French versions of fairy tales be compared and contrasted in class. To this end, German language students were trained to perform/tell fairy tales in kindergartens and primary schools. The participatory lecture concluded with a plenary session, in which the use of fairy tales in interdisciplinary, cooperative and performative foreign language teaching was discussed.

Stefanie Giebert (HTWG Konstanz) presented a plethora of storytelling games 
aimed at improving fluency. The selected games could be played in classrooms where space is limited, as well as requiring few or no props. They were also chosen to be suitable for learners and teachers with little or no experience with drama techniques.

Eva Göksel (University of Zurich/University of Teacher Education Zug) and Tomáš Andrášik (Masaryk University) offered a glimpse into the didactic potential of process drama in teacher training. After receiving an overview of a drama-based course for future English language teachers, the workshop participants experienced parts of a process drama first-hand. The workshop aimed to demonstrate that drama-based pedagogy facilitates the development of language, personal, and social skills, as well as guiding the exploration of various content-based topics in literature, culture, history and psychology.

Hedwig Golpon (Ernst-Moritz-Arndt-University, Greifswald) led a workshop exploring the potential of drama-based pedagogies in literacy education. Bertolt Brecht's parables (Stories of Mr. Keuner) were explored through reading, inquiry, and role-play. In addition, the workshop leader shared highlights from her personal teaching journey using drama-based pedagogies in South America, in particular in Asuncion, Buenos Aires und Sao Paulo. The various talks and workshops were followed by a conference dinner and an evening of improv theatre.

On the second day, Marla Levenstein and Olga Kiwus (free lance drama pedagogues) explored approaches to 'inclusion' through a role-play called "Coach". Workshop participants co-created a fictional setting in order to debate an aspect of inclusion in role. The workshop leaders demonstrated that the role-play is adaptable for various ages and levels of language learners. Meanwhile, Nicole Küpfer (drama in education Switzerland, Zurich) and her workshop participants explored small town life, as they delved into the short story "Small Avalanches" by Joyce Carol Oates. The group tested a sequence of drama techniques to set the scene for the story, to familiarize the group with its key aspects, and to explore the characters through close reading and use of drama. The workshop content was developed for high school and adult learners of English as a second/foreign language (level B1-C1).

Saturday's keynote was given by Christian Krekeler, professor for German as a Foreign Language at Konstanz University of Applied Sciences. The talk "drama in education and assessment - can creativity be standardised?" explored assessment in second/foreign language teaching and attempted to bridge the gap to assessing drama in language education. Focusing on testing, this talk explored task design: What tasks are suitable for measuring pedagogical goals as well as assessing performance? The talk concluded with a final plea for open and transparent assessment.

The afternoon was dedicated to learner experiences of drama-based pedagogies, as well as the potential of 'spoken word' in language teaching. Simona Bora, (Essex University), held a talk: "From learners' interviews: investigating attitudes towards dramatic approaches within the L2 compulsory curriculum". The talk underlined the necessity of researching students' attitudes 
towards the use of dramatic approaches in the classroom, as well as advocating for greater use of authentic plays in intra-curricular settings.

In her talk "From Stage to Page: Spoken Word Poetry in the EFL Classroom" Lioba Schreyer (Ruhr University Bochum) explored the possibilities of spoken word poetry in the language classroom. Using video examples featuring the work of poet Sarah Kay, the talk proposed that spoken word poetry be used as a bridge between teaching popular and classical literature to an interactive classroom.

The conference ended on a vibrant note with a plenary session and an impromptu song, taught to the group by Albert Bahmann (HTWG Konstanz). The next conference is planned for July 2018. Further details can be found on the Drama in Education Days webpage: http://dramapaedagogik. de. 